University of Wollongong

Research Online

Faculty of Commerce - Papers (Archive)

Faculty of Business and Law

$1-1-2009$

\title{
Malmquist indices of productivity change in Botswana's financial institutions
}

Boitumelo Dudu Moffat

University of Wollongong, bdm855@uow.edu.au

Abbas Valadkhani

University of Wollongong, abbas@uow.edu.au

Charles Harvie

University of Wollongong, charvie@uow.edu.au

Follow this and additional works at: https://ro.uow.edu.au/commpapers

Part of the Business Commons, and the Social and Behavioral Sciences Commons

\section{Recommended Citation}

Moffat, Boitumelo Dudu; Valadkhani, Abbas; and Harvie, Charles: Malmquist indices of productivity change in Botswana's financial institutions 2009, 28-43.

https://ro.uow.edu.au/commpapers/675

Research Online is the open access institutional repository for the University of Wollongong. For further information contact the UOW Library: research-pubs@uow.edu.au 


\title{
Malmquist indices of productivity change in Botswana's financial institutions
}

\begin{abstract}
The productivity and efficiency of the financial sector is pivotal to the attainment of economic growth and development in developed and developing economies alike, and is of particular interest in the wake of financial sector reform and restructuring. This study applies the Malmquist productivity index to measure and decompose the total factor productivity change of ten financial institutions in Botswana in its postreform era, covering the period 2001-2006, into a 'catching up' or efficiency change, and a 'frontier shift' or technological change. The robustness and sensitivity of the empirical results presented are assessed by comparing outcomes from different input and output combinations derived from using the value added, intermediation and operating approaches. The empirical results indicate a loss or little productivity gain in Botswana's financial institutions, arising mainly from technological regress. Policy implications from this are highlighted in the paper.
\end{abstract}

\section{Keywords}

botswana, financial, institutions, productivity, change, indices, malmquist

Disciplines

Business | Social and Behavioral Sciences

\section{Publication Details}

Moffat, B., Valadkhani, A. \& Harvie, C. (2009). Malmquist indices of productivity change in Botswana's financial institutions. Global Business and Economics Review, 11 (1), 28-43. 


\title{
Malmquist indices of productivity change in Botswana's financial institutions
}

\section{Boitumelo Moffat, Abbas Valadkhani* and Charles Harvie}

\author{
School of Economics \\ University of Wollongong \\ NSW 2522, Australia \\ Fax: +612-42213725 \\ E-mail: bdm855@uow.edu.au \\ E-mail: abbas@uow.edu.au \\ E-mail: charvie@uow.edu.au \\ *Corresponding author
}

\begin{abstract}
The productivity and efficiency of the financial sector is pivotal to the attainment of economic growth and development in developed and developing economies alike, and is of particular interest in the wake of financial sector reform and restructuring. This study applies the Malmquist productivity index to measure and decompose the total factor productivity change of ten financial institutions in Botswana in its postreform era, covering the period 2001-2006, into a 'catching up' or efficiency change, and a 'frontier shift' or technological change. The robustness and sensitivity of the empirical results presented are assessed by comparing outcomes from different input and output combinations derived from using the value added, intermediation and operating approaches. The empirical results indicate a loss or little productivity gain in Botswana's financial institutions, arising mainly from technological regress. Policy implications from this are highlighted in the paper.
\end{abstract}

Keywords: Botswana; technical and pure technical efficiencies; data envelopment analysis; DEA; financial institutions.

Reference to this paper should be made as follows: Moffat, B., Valadkhani, A. and Harvie, C. (2009) 'Malmquist indices of productivity change in Botswana's financial institutions', Global Business and Economics Review, Vol. 11, No. 1, pp.28-43.

Biographical notes: Ms. Boitumelo Moffat is currently undertaking her $\mathrm{PhD}$ at the School of Economics, the University of Wollongong, Australia. Her research interests include areas such as data envelopment analysis, applied econometrics, economic development and financial and monetary economics.

Dr. Abbas Valadkhani is an Associate Professor of Economics at the University of Wollongong, Australia. Previously, he has held Lecturer posts at the Queensland University of Technology and the University of Newcastle in Australia. He has over 60 publications in refereed journals in the areas of applied econometrics, macroeconometric model building and international financial and monetary economics. His current research interests include productivity and growth, the Australian macroeconomy, the pre- and post-GST effects on inflation and financial modelling. 
Dr. Charles Harvie holds a PhD in Economics from the University of Warwick (UK) and is currently an Associate Professor at the School of Economics of the University of Wollongong, Australia. He has published over 150 papers in refereed journals, book chapters and refereed conference papers, 15 edited and authored books on the economies of East Asia, economic integration in East Asia and SMEs in East Asia. His current research interests include economic integration in East Asia, private small business development in Vietnam and China and modelling the macreconomic impact of resource price shocks.

\section{Introduction}

The financial system in Botswana has undergone major or significant structural and institutional changes in recent years. Throughout the 1980s a series of financial reforms were introduced to boost the efficiency and productivity of financial institutions by enhancing the crucial role of market forces (Bank of Botswana (BoB), 1999). New entrants to the system and new products such as Automated Teller Machines (ATMs), credit and debit card services were permitted as a result.

Capital expenditure on equipment, however, may give a poor indication of catch-up of technology. The present paper is concerned with an in-depth assessment of financial sector productivity by means of employing a Malmquist Index. The context of this paper is Botswana, where no study has so far assessed the productivity of its financial institutions. This issue is of paramount importance for Botswana, where various economic reforms have been initiated with the aim of improving the efficiency and productivity of its financial institutions.

Financial institutions in Botswana, especially the commercial banks, have registered high profits during the past decade. These high profit levels have persisted in spite of the entry of new banks, mostly foreign owned institutions, and increased competition in the sector, which can be expected to eventually reduce these profits. Nevertheless, as Jefferis (2007) argues, persistently high profits suggest that competition in the financial sector remains inadequate. A key issue is whether financial institutions can be efficient and productive when there is limited competition in the sector? Ataullah and Le (2006), Chen et al. (2005) and Canhoto and Dermine (2003) find that competition is one of the most important factors enhancing firm efficiency and productivity.

With increased competition, some institutions may find that their competitive advantage lies in financing smaller firms. Sacerdoti (2005) views that as large foreign banks enter the market they are expected to concentrate their lending to larger firms, which they may have a competitive advantage in financing. This may induce local firms, possibly with a better knowledge of local conditions, to expand financing of smaller businesses and individuals.

Jefferis (2007) argues that, in the context of Botswana's financial sector, there is greater focus on lending to households (rather than businesses), high bank charges, reliance on Bank of Botswana Certificates for assets and income, and on the extension of banking services to rural areas. Siphambe et al. (2005) state that this lopsided approach can be attributed, to some extent, to the lack of innovation in Botswana's banking system. Again, this leads to the question of how can financial institutions be productive if there is a lack of innovation in the sector? Avkiran (2000) found that technological innovation 
plays a principal role in shaping financial service delivery in Australia, for example alternative ways of customer access and product distribution enabled by technological innovation have lowered barriers to entry. Therefore, technological innovation can be regarded as a sign of dynamic efficiency where financial institutions take advantage of new cost-effective technologies and pursue product and market development.

By comparing annual changes in the productivity of financial institutions, it is possible to identify discernable trends, if any, in the productivity of the financial sector as a whole. The sources of productivity growth, or decline, can be estimated by decomposing the Malmquist productivity indices into their constituent components, which indicate the extent to which the productivity change for each institution is due to a shift in the efficient frontier or to a process of moving closer to, or further away from, the efficient frontier. These components are often referred to as the 'frontier shift' and 'catch-up' elements of productivity change, respectively.

The remainder of this paper is structured as follows: Section 2 briefly reviews the literature on the analysis of efficiency changes through time. Section 3 focuses on the theoretical background of the Malmquist productivity indices and how to measure them. Section 4 deals with the sensitive issue (as different ways of input-output classifications may lead to different efficiency indices) of the specification of inputs and outputs employed in the evaluation of technical efficiency, and technical change in financial institutions. Section 5 presents the resultant indices of productivity, efficiency and technical change for Botswana's ten financial institutions. The paper ends with some concluding remarks and policy implications in Section 6.

\section{Literature review}

Berg et al. (1992) presented the first application of the Malmquist index to measure productivity growth in the Norwegian banking system in the pre and post deregulation era, using the value added approach. This will be described later in the paper. Their analysis revealed that productivity exhibited a lacklustre performance in the pre-deregulation period, but it markedly improved in the post-deregulation period. Their results clearly support the view that deregulation led to a more competitive environment, especially for larger banks.

Utilising a Malmquist total factor productivity change index, Isik and Hassan (2003) examined productivity growth, efficiency change and technical progress in Turkish commercial banks. They found that all types of Turkish banks (both private and public) recorded significant productivity gains, driven mostly by efficiency advances and more effective management of resources rather than technical progress. Mukherjee et al. (2001) in their study of productivity growth in 201 large US banks found that productivity grew, on average, at $4.5 \%$ per year, particularly among banks with a large asset size.

After decomposing the overall productivity change into efficiency change and technological change in measuring productivity growth Jeanneney et al. (2006) found that the Chinese banking system had improved its total factor productivity, but that this growth in productivity was mainly attributable to technical progress rather than to an improvement in efficiency. Worthington (1999) found that efficiency gains in Australian financial services were largely the result of improvements in technical efficiency rather than scale efficiency. He also asserted that this productivity growth was mainly achieved 
by credit unions with a small number of members and a large asset base. According to Worthington (1999), technological progress, on the other hand, was higher mainly among those financial institutions which had a relatively larger proportion of residential and commercial loans.

Drake (2001) studied efficiency and productivity changes in the UK banking system and found that for the UK banks scale inefficiencies were a more severe problem than $\mathrm{X}$-inefficiencies, particularly for both ends of the bank-size spectrum. Drake (2001) also provided some evidence that very large banks were more X-efficient than their smaller competitors, particularly in the latter years of the study period. Drake's Malmquist productivity indices suggested that, on the whole, UK banks exhibited positive productivity growth over the period. For most banks the productivity growth was the net result of a mixture of a positive frontier shift and negative catch-up.

In investigating X-efficiency and productivity change in Australian banks, Neal (2004) applied Data Envelopment Analysis (DEA) and the Malmquist productivity indexes and found that banks exhibited a higher level of allocative efficiency than technical efficiency. Large banks performed on the best practice frontier for most years in the sample. The Malmquist indices of productivity change in this study suggested a significant improvement in the efficiency of the banking sector over the period 1995-1999. According to Neal (2004), total factor productivity grew by an annual average of $7.6 \%$ and technological changes led to an annual $11.5 \%$ shift in the banking frontier.

In this paper a non-parametric DEA is adopted by applying the Malmquist index approach to analyse the productivity of financial institutions in Botswana. Even though DEA assumes no random error, its advantages in the context of this study outweigh its disadvantages. One of these advantages, which is more relevant to this study, is that DEA works well with small sample sizes. Unlike countries such as the USA where there are very large numbers of institutions, there are only relatively few financial institutions in Botswana and thus the industry is less suited to analysis using parametric techniques such as stochastic production functions. Of particular interest to this study is a paper by Drake (2001), who used a sample size of nine banks to study technical and scale efficiencies and productivity gains in the UK banking sector. His models successfully distinguished varying efficiency differences among UK banks.

\section{Malmquist index of productivity change}

According to Coelli et al. (2005) technical efficiency is defined as the ability of a firm to use a minimal amount of inputs to produce an optimum output. Technical efficiency only provides a measure of the efficiency of firms relative to the best-practice firms in the sample. Overtime, however, the level of output a firm is capable of producing will increase/decrease due to technological changes that affect its ability to optimally combine inputs and outputs. These technological changes cause the production possibility frontier to shift upwards (downwards) as more (less) outputs are obtainable from the same level of inputs. Thus, productivity improvement over time may be attributable to either technical efficiency enhancements (catching up with their own frontier) or to technological advancements (as the frontier shifts up) or both. 
In this study we apply the Malmquist productivity index to decompose total productivity change into technical change (frontier shift) and technical efficiency change. Following Thanassoulis (2001) the Malmquist productivity change index (MI) may be formally stated as follows:

$$
M I^{t+1}\left(y^{t+1}, x^{t+1}, y^{t}, x^{t}\right)=\left[\frac{D^{t}\left(y^{t+1}, x^{t+1}\right)}{D^{t}\left(y^{t}, x^{t}\right)} \times \frac{D^{t+1}\left(y^{t+1}, x^{t+1}\right)}{D^{t+1}\left(y^{t}, x^{t}\right)}\right]^{0.5}
$$

where:

$$
\begin{aligned}
M I= & \text { the productivity of the most recent production point using period }(\mathrm{t}+1) \\
& \text { relative to the earlier production using period }(\mathrm{t}) \text { technology } \\
D s= & \text { denotes input distance functions } \\
y= & \text { the level of outputs } \\
x= & \text { the level of inputs. }
\end{aligned}
$$

A value of $M I$ that is greater than unity indicates a growth in total productivity over the two periods. The Malmquist Index in Equation (1) can be decomposed into a catch-up component and a boundary-shift component as follows:

$$
M I^{t+1}\left(y^{t+1}, x^{t+1}, y^{t}, x^{t}\right)=\underbrace{\frac{D^{t+1}\left(y^{t+1}, x^{t+1}\right)}{D^{t}\left(y^{t}, x^{t}\right)}}_{\text {'Catch-up'component }} \times \underbrace{\left[\frac{D^{t}\left(y^{t+1}, x^{t+1}\right)}{D^{t+1}\left(y^{t+1}, x^{t+1}\right)} \times \frac{D^{t}\left(y^{t}, x^{t}\right)}{D^{t+1}\left(y^{t}, x^{t}\right)}\right]^{0.5}}_{\text {'Boundary-shift'component }} .
$$

The catch-up component compares the closeness of financial institution $f_{o}$ in each period to that of other period's efficiency boundary. If the catch-up component value is equal to unity, then financial institution $f_{o}$ will have the same distance from the respective boundaries in periods $(t)$ and $(t+1)$. A catch-up value that is greater than unity means that financial institution, $f_{o}$ will perform more efficiently in period $(\mathrm{t}+1)$ than in period (t). Similarly, a catch-up value less than one indicates that financial institution, $f_{o}$ has become less efficient in period $(t+1)$ than in period $(t)$.

For the boundary-shift component a value of greater than one represents productivity gain by a financial institution $f_{o}$, implying that for a given amount of output it uses lower input levels in period $(\mathrm{t}+1)$ than in period $(\mathrm{t})$. On the other hand a boundary shift value that is less than one means productivity losses have been incurred by financial institution $f_{o}$, in that it uses more inputs in period $(\mathrm{t}+1)$ than in period $(\mathrm{t})$ to produce the same amount of output. When the boundary shift value is equal to one then there is neither productivity gain nor loss in both periods.

In order to calculate the Malmquist indices it is necessary to solve several sets of linear programming problems. We assume that there are $N$ financial institutions and that each consumes varying amounts of $M$ different inputs to produce $S$ different outputs. The objective is to construct a nonparametric envelopment frontier over the data points such that all observed points lie on or below the production frontier. Assuming constant returns to scale the following models for periods $(t)$ and $(t+1)$ can be formulated: 
Min

$l_{o}$

Subject to:

$$
\begin{aligned}
& \sum_{f=1}^{N} \lambda_{f} x_{i f_{o}}{ }^{t}-l_{o} x_{i f_{o}}{ }^{t} \leq 0 \quad \text { where } \quad i=1 \ldots . M \\
& \sum_{f=1}^{N} \lambda_{f} y_{r f}{ }^{t} \geq y_{r f_{o}}{ }^{t} \quad \quad \text { where } \quad r=1 \ldots . S \\
& \lambda_{f} \geq 0, f=1 \ldots . N \geq 0
\end{aligned}
$$

Min

$l_{o}$

Subject to:

$$
\begin{aligned}
& \sum_{f=1}^{N} \lambda_{f} x_{i f_{o}}{ }^{t+1}-l_{o} x_{i f_{o}}{ }^{t+1} \leq 0 \quad \text { where } \quad i=1 \ldots . M \\
& \sum_{f=1}^{N} \lambda_{f} y_{r f}{ }^{t+1} \geq y_{r f_{o}}{ }^{t+1} \quad \text { where } \quad r=1 \ldots . S \\
& \lambda_{f} \geq 0, f=1 \ldots . N \geq 0 .
\end{aligned}
$$

Where $x_{i f}$ and $y_{r f}$ are levels of the $i$-th input and $r$-th output for financial institution $f$, respectively. The value of $l_{o}$ will be the efficiency score for financial institution $f$. In Equations (3) and (4) each financial institution's production points are compared with technologies from the same time period. The cross-time period radial technical input efficiencies are then calculated as follows:

Min $\quad l_{o}$

Subject to:

$$
\begin{aligned}
& \sum_{f=1}^{N} \lambda_{f} x_{i f}{ }^{t}-l_{o} x_{i f_{o}}{ }^{t+1} \leq 0 \quad \text { where } \quad i=1 \ldots . M \\
& \sum_{f=1}^{N} \lambda_{f} y_{r f}{ }^{t} \geq y_{r f_{o}}{ }^{t+1} \quad \text { where } \quad r=1 \ldots . S \\
& \lambda_{f} \geq 0, f=1 \ldots . N \geq 0
\end{aligned}
$$

Min

$l_{o}$

$$
\begin{aligned}
& \text { Subject to: } \quad \sum_{f=1}^{N} \lambda_{f} x_{i f}{ }^{t+1}-l_{o} x_{i f_{o}}{ }^{t} \leq 0 \quad \text { where } \quad i=1 \ldots . M \\
& \sum_{f=1}^{N} \lambda_{f} y_{r f}{ }^{t+1} \geq y_{r f_{o}}{ }^{t} \quad \text { where } \quad r=1 \ldots . S \\
& \lambda_{f} \geq 0, f=1 \ldots . N \geq 0 .
\end{aligned}
$$


Equations (5) and (6) present the cross-time period radial technical input efficiency of financial institution $f_{o}$. Following Fare et al. (1990) the above equations (Equations 3-6) can be used to calculate the following five efficiency and productivity indices for each unit as well as measure technical progress over time:

1 the Technical Efficiency Change (TEC) measure based on constant returns to scale technology

2 the measure of Technological Change (TC)

3 the measure of Pure Technical Efficiency Change (PTEC) based on variable returns to scale technology

4 the measure of Scale Efficiency Change (SEC)

5 Total Factor Productivity Change (TFPC) which quantifies the degree of productivity.

If TFPC $>1$ then one can argue that productivity gains have occurred, but if it is less than one then the firm has incurred productivity losses during the period under investigation. Technical efficiency follows an upward trajectory if TEC exceeds one and vice versa. Similarly, if TC is more than one this is evidence of technical progress, but if TC is less than one the outcome could be technological regress.

One can identify the main sources of productivity gains or losses by analysing the magnitudes of TEC and TC. For instance, if TEC is greater than TC then productivity gains are more likely to be as a result of improvements in efficiency. Conversely, if TEC $<$ TC then productivity gains are mostly attributable to technological progress. Given that overall technical efficiency is the product of pure technical change and scale efficiency (i.e., TEC $=$ PTEC $\times$ SE), the main determinants of efficiency changes can be numerically traced as follows: if PTEC $>$ SE then an improvement in pure technical efficiency is highly likely to explain most of the efficiency changes. However, if PTEC $<$ SE it is highly likely that an improvement in scale efficiency has generated the resulting efficiency changes.

\section{Specification of inputs and outputs}

There is no consensus in the literature regarding the specification of outputs and inputs in frontier modelling of financial institutions (see for example, Berger and Humphery, 1997; Favero and Papi, 1995). However, it is commonly acknowledged that the choice of variables in efficiency studies could significantly affects the results. The problem is compounded by the fact that the choice of variables (both inputs and outputs) is often constrained by the availability of data on relevant variables, particularly in the context of developing countries. The input and output measurements are especially difficult to quantify because the bulk of financial services/products are jointly produced, and prices are typically assigned to a bundle of financial services. However, there are several different approaches in the literature regarding the specification of input-output mix. Inter alia, these include the production approach, the intermediation approach and, more 
recently, the modern approach, the operating approach, the asset approach and the user cost approach. For a detailed account of these approaches see, for example, Das and Ghosh (2006) and Favero and Papi (1995).

One can argue that each method has its own merit and can be considered appropriate if their underlying assumptions hold. It is apparent that financial institutions undertake diverse functions simultaneously. Given data constraints, we examine the robustness and sensitivity of our estimated efficiency scores by using three approaches: value-added, intermediation and operating.

According to the intermediation approach, financial institutions are regarded as intermediators that transform and transfer financial assets from savers to borrowers. Financial institutions produce intermediation services through the collection of deposits and other liabilities and then utilise them in interest-earning assets, such as loans, securities and other types of investments. This approach includes both operating and interest expenses as inputs, whereas loans and other major assets count as outputs. This approach has been applied in a number of developing countries inter alia by Sathye (2003), Paxton (2006) and Das and Ghosh (2006).

The value-added approach, on the other hand, identifies assets or liabilities in balance-sheet as outputs because they lead to the generation of more value added. In general, under this approach, the major categories of deposits and loans are viewed as outputs because they constitute a significant proportion of the value added component (Das and Ghosh, 2006).

Finally, according to Leightner and Lovell (1998), given total business costs incurred, the operating approach (or income-based approach) considers financial institutions as business units with the final objective of generating more revenues. This approach defines institutions' output as total revenues (interest and non-interest) and their inputs as total expenses (paid interest and operating expenses). Selected inputs and outputs under the three alternative approaches employed in the study are summarised in Table 1.

Table 1 Choice of input/output variables under the three approaches ${ }^{\mathrm{a}}$

\begin{tabular}{lll}
\hline Approach & Inputs & Outputs \\
\hline Intermediation approach & Deposits & Loans \\
& Labour (salaries) & \\
& Capital related operating expenses & Investment \\
Value-added approach & Labour (salaries) & Loans \\
& Capital related operating expenses & Investment \\
& Interest expenses & Deposits \\
Operating approach & Interest expenses & Interest income \\
& Labour(salaries/employee expenses) & \\
& Capital related operating expenses & Non-interest income \\
\hline
\end{tabular}

Notes: ${ }^{a}$ All inputs/outputs variables are measured in thousands of Pula.

b The implication that labour salaries are a good proxy for labour's input to actual output is not necessarily established beyond doubt. 
Since DEA is appropriate for efficiency analysis even if the sample size is small, we utilise this technique to examine only those financial institutions for which the required data for the three approaches were available during the period 2001-2006. The sample, therefore, includes ten financial institutions comprising both banking and non-banking institutions. ${ }^{1}$

\section{Empirical results}

In the preceding sections we defined the Malmquist indices of productivity changes relative to a reference technology. In this section Equations (3) to (6) are used to examine productivity changes from 2001-2002 to 2005-2006 by:

- measuring the overall productivity changes over the period under investigation

- decomposing the total changes into the 'catching-up' effect (i.e., efficiency change) and a 'frontier shift' effect (i.e., technological change)

- further decomposing the 'catching-up' effect to see whether the improvements are as a result of enhancements in technical efficiency or increases in scale efficiency or both.

Table 2 presents the efficiency change, technical change, pure technical efficiency, scale efficiency and finally TFPC for each of the ten financial institutions in Botswana under the three approaches. In order to facilitate comparison between the results obtained from adopting each of the three approaches, all of the columns of Table 2 are sorted in terms of the magnitude of the Malmquist total factor productivity index (the last column). It should be borne in mind that for each financial institution in the sample the TFPC is the product of efficiency and technical change. If this index is greater (less) than unity, it means that there has been a productivity gain (loss), an efficiency increase (decrease) or technical progress (regress). Similarly, the overall efficiency change is the product of PTEC and SEC.

The different results obtained under the approaches indicate that DEA is a flexible technique which produces efficiency scores that are different when alternative sets of inputs and outputs are used. As can be seen from Table 2, under the value-added approach for example, Standard Chartered Bank has recorded an average positive increase in total factor productivity of $8.7 \%(1.087-1.000)$, whereas under the operating approach this gain is only $5.4 \%$. The increase in productivity under the value-added approach $(8.7 \%)$ can then be decomposed into $9.3 \%$ technological progress and a loss in efficiency of $0.5 \%$. This result contrasts with the operating approach, where the corresponding 5.4\% productivity gain consists of an efficiency gain of $17 \%$ and technological regress of $10.1 \%$. Under the intermediation approach, Standard Chartered Bank registered a $3.4 \%$ fall in total factor productivity, mainly as a result of technological regress. 
Table 2 Malmquist index summary of firm means, 2001/2002-2005/2006

\begin{tabular}{|c|c|c|c|c|c|}
\hline Firm & $\begin{array}{l}\text { Efficiency } \\
\text { change }\end{array}$ & $\begin{array}{l}\text { Technical } \\
\text { change }\end{array}$ & $\begin{array}{c}\text { Pure } \\
\text { technical } \\
\text { efficiency }\end{array}$ & $\begin{array}{c}\text { Scale } \\
\text { efficiency }\end{array}$ & $\begin{array}{c}\text { Total factor } \\
\text { productivity } \\
\text { change }\end{array}$ \\
\hline \multicolumn{6}{|l|}{ Value-added approach } \\
\hline Bank of Baroda & 1.000 & 1.333 & 1.000 & 1.000 & 1.333 \\
\hline First National Bank & 1.167 & 0.970 & 1.024 & 1.140 & 1.132 \\
\hline Standard Chartered Bank & 0.995 & 1.093 & 1.011 & 0.983 & 1.087 \\
\hline $\begin{array}{l}\text { Botswana Development } \\
\text { Corporation }\end{array}$ & 1.109 & 0.903 & 1.140 & 0.972 & 1.002 \\
\hline Barclays Bank & 0.967 & 1.017 & 1.000 & 0.967 & 0.983 \\
\hline Botswana Building Society & 1.035 & 0.932 & 1.000 & 1.035 & 0.965 \\
\hline Stanbic Bank & 1.016 & 0.909 & 1.000 & 1.016 & 0.924 \\
\hline Botswana Savings Bank & 1.000 & 0.915 & 1.000 & 1.000 & 0.915 \\
\hline African Banking Corporation & 0.897 & 1.003 & 0.762 & 1.177 & 0.899 \\
\hline National Development Bank & 0.873 & 0.982 & 0.990 & 0.882 & 0.857 \\
\hline \multicolumn{6}{|l|}{ Intermediate approach } \\
\hline First National Bank & 1.257 & 0.980 & 1.228 & 1.023 & 1.231 \\
\hline $\begin{array}{l}\text { Botswana Development } \\
\text { Corporation }\end{array}$ & 1.241 & 0.984 & 1.232 & 1.008 & 1.222 \\
\hline Botswana Building Society & 1.118 & 0.957 & 1.000 & 1.117 & 1.070 \\
\hline Bank of Baroda & 1.000 & 0.992 & 1.000 & 1.000 & 0.992 \\
\hline Standard Chartered Bank & 1.001 & 0.965 & 1.005 & 0.996 & 0.966 \\
\hline Barclays Bank & 1.025 & 0.936 & 1.000 & 1.025 & 0.959 \\
\hline Botswana Savings Bank & 1.000 & 0.954 & 1.000 & 1.000 & 0.954 \\
\hline African Banking Corporation & 1.015 & 0.930 & 1.000 & 1.015 & 0.944 \\
\hline Stanbic Bank & 0.925 & 0.917 & 0.977 & 0.946 & 0.848 \\
\hline National Development Bank & 0.805 & 0.898 & 1.000 & 0.805 & 0.723 \\
\hline \multicolumn{6}{|l|}{ Operating approach } \\
\hline Botswana Building Society & 1.006 & 1.052 & 1.000 & 1.006 & 1.058 \\
\hline Standard Chartered Bank & 1.172 & 0.899 & 1.003 & 1.169 & 1.054 \\
\hline Barclays Bank & 1.141 & 0.903 & 1.000 & 1.141 & 1.031 \\
\hline Botswana Savings Bank & 1.000 & 0.962 & 1.000 & 1.000 & 0.962 \\
\hline $\begin{array}{l}\text { Botswana Development } \\
\text { Corporation }\end{array}$ & 1.110 & 0.837 & 1.083 & 1.025 & 0.930 \\
\hline First National Bank & 1.135 & 0.810 & 1.000 & 1.135 & 0.920 \\
\hline Bank of Baroda & 1.000 & 0.883 & 1.000 & 1.000 & 0.883 \\
\hline National Development Bank & 0.921 & 0.959 & 0.999 & 0.922 & 0.883 \\
\hline Stanbic Bank & 0.956 & 0.884 & 0.925 & 1.033 & 0.845 \\
\hline African Banking Corporation & 0.818 & 0.839 & 0.701 & 1.168 & 0.686 \\
\hline
\end{tabular}


Looking at the results obtained using the value-added approach, six of the ten institutions (see the last column of Table 2) exhibited an overall loss in productivity ranging from $1.7 \%$ for Barclays Bank to $14.3 \%$ for National Development Bank (NDB). The decomposition of this productivity change (the last column) into efficiency change and technical change indicates that for all institutions, with the exception of Barclays Bank, Standard Chartered Bank, Bank of Baroda and African Banking Corporation (ABC), there is evidence of negative frontier shifts ranging from a minimum of $1.8 \%$ (NDB) to a maximum of $9.7 \%$ (Botswana Development Corporation) (see Table 2, Column 2). These results indicate that $60 \%$ of Botswana's financial institutions experienced negative technical change during the period 2001-2006. On the other hand, Barclays Bank, NDB and $\mathrm{ABC}$ exhibited negative catching up over the same period (see Table 2, Column 1) ranging from a minimum of $0.5 \%$ (Standard Chartered Bank) to a maximum of $12.7 \%$ (NDB). For three of these four institutions a poor scale efficiency performance was the primary culprit.

Results obtained from the intermediate approach in terms of total productivity, efficiency and technical change, indicate an even weaker performance. Only three institutions achieved an increase in productivity over the period $2001-2006,{ }^{2}$ all institutions experienced negative technical change, although eight of the institutions experienced no or positive catch up in terms of efficiency. Of the two institutions that experienced a negative efficiency change, the primary culprit was again a poor scale efficiency performance.

Results from the operating approach are also mixed. Only three institutions achieved an increase in productivity, ${ }^{3}$ only one institution achieved positive technical change, while seven institutions experienced no or positive catch up in terms of efficiency. Of the three institutions that experienced a negative efficiency change the primary culprit for two of these was, this time, a poor technical efficiency performance.

Despite the mixed outcomes from each of the three approaches a number of observations are worthy of emphasis. First, the NDB is by far the worst performer in terms of efficiency change under both the value added and intermediate approaches, and both agree that this was primarily due to a poor scale efficiency performance. While the operating approach does not rank this institution as last in terms of efficiency change it still performs poorly, and, again, this is primarily due to a poor scale efficiency performance. This bank is a public sector bank which has the aim of lending for agricultural activities which are unpredictable, and hence prone to high default risks. Furthermore, it is noticeable that the underperformance of NDB is far more pronounced under the intermediation approach, with a catch up figure of only 0.805 .

Second, Table 2 shows that under all three approaches the Bank of Baroda and the Botswana Savings Bank (BSB) exhibited no evidence of catching up with the efficiency frontier over the period in question, because they remained on the frontier over the entire period. Third, while no single bank achieved a positive increase in productivity using all three approaches, the value added and intermediation approaches recognised positive increases for both the First National Bank and the Botswana Development Corporation. Both approaches agree that this was primarily due to positive efficiency changes arising from pure technical efficiency. Finally, based on all three approaches, the Stanbic Bank, NDB and ABC are the worst performers in terms of productivity. For the Stanbic Bank this is unanimously due to a poor technical change performance. For the NDB this is unanimously due to a poor catching up in efficiency change, and more specifically a very poor scale efficiency performance. For the $\mathrm{ABC}$ 
the explanation for the poor productivity performance is more mixed. The value added and operating approaches suggest that this is primarily due to a poor efficiency change performance while the intermediate approach suggests it is, instead, due to a poor technical change performance. The value added and operating approaches clearly indicate that the poor efficiency performance is driven by very poor pure technical efficiency outcomes.

Summary statistics of calculated values of the various efficiency measures are presented in Table 3 . Table 4 presents the means for all of the financial institutions for each of the sample years based on all three approaches. In addition, for each approach, Malmquist index averages ${ }^{4}$ over the entire period (bottom row) are computed for each of the approaches.

Table 3 Descriptive statistics: efficiency measures (2001/2002-2005/2006)

\begin{tabular}{lcccc}
\hline Types of efficiency & Minimum & Maximum & Mean & Standard deviation \\
\hline Value-added approach & & & & \\
Efficiency change & 0.930 & 1.140 & 1.005 & 0.080 \\
Technical change & 0.930 & 1.190 & 1.003 & 0.108 \\
Pure technical change & 0.930 & 1.070 & 0.990 & 0.061 \\
Scale efficiency & 0.960 & 1.060 & 1.015 & 0.038 \\
Total factor productivity change & 0.910 & 1.130 & 1.006 & 0.106 \\
Intermediation approach & & & & \\
Efficiency change & 0.980 & 1.100 & 1.032 & 0.052 \\
Technical change & 0.820 & 1.120 & 0.956 & 0.112 \\
Pure technical change & 1.000 & 1.090 & 1.041 & 0.039 \\
Scale efficiency & 0.950 & 1.010 & 0.991 & 0.026 \\
Total factor productivity change & 0.870 & 1.240 & 0.989 & 0.150 \\
Operating approach & & & & \\
Efficiency change & 0.790 & 1.540 & 1.048 & 0.289 \\
Technical change & 0.580 & 1.080 & 0.921 & 0.200 \\
Pure technical change & 0.830 & 1.080 & 0.969 & 0.088 \\
Scale efficiency & 0.940 & 1.430 & 1.070 & 0.205 \\
Total factor productivity change & 0.820 & 0.970 & 0.920 & 0.063 \\
\hline
\end{tabular}

As indicated in Table 4, there was an overall mean annual decrease in total factor productivity over the period ending December 2006 under both the intermediate and operating approaches. The value added approach indicates a very modest improvement in the mean total factor productivity over the same period. In the case of Botswana's financial institutions the poor overall productivity performance over the entire period is primarily due to technological regress (downward shift of the frontier). This is 
particularly noticeable for the intermediate and operating approaches. The reason for this may be due to the fact that most of these institutions have not embarked on the use of new technologies, such as telephone banking and internet banking, which, according to Avkiran (2000), have been found to be cost effective ways for the delivery of financial services.

Table 4 Malmquist index summary of annual means, 2001-2006

\begin{tabular}{lccccc}
\hline & $\begin{array}{c}\text { Efficiency } \\
\text { change }\end{array}$ & $\begin{array}{c}\text { Technical } \\
\text { change }\end{array}$ & $\begin{array}{c}\text { Pure technical } \\
\text { change }\end{array}$ & $\begin{array}{c}\text { Scale } \\
\text { efficiency }\end{array}$ & $\begin{array}{c}\text { Total factor } \\
\text { productivity } \\
\text { change }\end{array}$ \\
\hline $\begin{array}{l}\text { Value-added approach } \\
\text { 2001/2002 }\end{array}$ & 1.008 & 0.930 & 0.972 & 1.037 & 0.938 \\
2002/2003 & 0.952 & 0.955 & 0.934 & 1.020 & 0.910 \\
$2003 / 2004$ & 0.930 & 1.191 & 0.937 & 0.993 & 1.108 \\
2004/2005 & 0.998 & 0.942 & 1.037 & 0.963 & 0.940 \\
2005/2006 & 1.135 & 0.999 & 1.070 & 1.061 & 1.134 \\
Mean & 1.002 & 0.999 & 0.989 & 1.014 & 1.002 \\
Intermediate approach & & & & & \\
2001/2002 & 1.001 & 0.961 & 0.996 & 1.005 & 0.962 \\
2002/2003 & 1.010 & 0.986 & 1.017 & 0.993 & 0.997 \\
2003/2004 & 0.977 & 0.888 & 1.033 & 0.946 & 0.867 \\
2004/2005 & 1.066 & 0.824 & 1.065 & 1.001 & 0.878 \\
2005/2006 & 1.104 & 1.122 & 1.094 & 1.009 & 1.239 \\
Mean & 1.031 & 0.951 & 1.040 & 0.991 & 0.980 \\
Operating approach & & & & & \\
2001/2002 & 0.978 & 0.970 & 0.993 & 0.985 & 0.948 \\
2002/2003 & 1.026 & 0.941 & 0.982 & 1.044 & 0.965 \\
2003/2004 & 1.540 & 0.579 & 1.077 & 1.430 & 0.892 \\
2004/2005 & 0.791 & 1.039 & 0.834 & 0.949 & 0.822 \\
2005/2006 & 0.904 & 1.078 & 0.957 & 0.944 & 0.974 \\
Mean & 1.020 & 0.900 & 0.956 & 1.057 & 0.918 \\
\hline
\end{tabular}

\section{Conclusions and policy implications}

This paper has analysed the productivity changes of financial institutions in Botswana over the period 2001 to 2006, utilising a DEA type Malmquist productivity index. This allowed the simultaneous analysis of changes in total productivity due to a catching-up effect and frontier movement. In order to assess the robustness and sensitivity of our results, we have employed three different approaches, namely, the value-added, intermediation and operating approaches, to specify different combinations of inputs and outputs. 
Overall, the results indicate that there has been a loss or little productivity growth at the frontier during the period in question, although there has been some improvement in the relative efficiency of most of the financial institutions in Botswana. The loss in total factor productivity has, therefore, been mostly due to technological regress. The reason for this may be that most of these institutions have not embarked on the use of new technologies such as telephone banking and internet banking in the delivery of their services. One may therefore conclude that financial institutions in Botswana lack dynamic efficiency, for example, the sector is dominated by three banks, Barclays Bank, Standard Chartered and First National Bank, and they accounted for $82 \%$ of total bank deposits in 2006 (BoB, 2007). Financial sector is not engaging actively in product innovation, and financial institutions are not making use of the most cost effective technologies. A lack of competition in the financial sector is likely to be the primary cause of this.

In terms of institution specific performance, Stanbic Bank, NDB and ABC are the worst performers in terms of productivity under all the three approaches. The NDB is the worst performer in terms of negative catch-up under the value added and intermediate approaches. This is a public sector bank with the aim of lending for agricultural activities which are unpredictable and hence prone to high default risks. The Bank of Baroda and BSB exhibited no evidence of catching up with the frontier over the period. This is because these two institutions were on the frontier over the entire period. However, these two banks exhibit a negative frontier shift under the intermediate and operating approaches, leading to their productivity losses.

There are a number of important policy implications arising from the results of this study. First, the poor overall productivity performance of Botswana's financial sector is cause for concern, as it is likely to contain the growth and development of the overall economy. As a consequence the authorities will need to rethink their reform measures to date with the objective of stimulating more competition in the marketplace. This could be achieved by: increasing the number of foreign banks operating in the economy; eliminating the distinction between banks and non bank financial institutions to allow competition in all sectors and segments of domestic financial markets; encourage consolidation of financial institutions through acquisitions and mergers with the stated objective of achieving clear efficiency outcomes; establish a single publicly owned financial institution with the stated objective of achieving state determined lending and development objectives while privatising all remaining state owned financial institutions; encourage the adoption of self-service technologies, such as telephone and internet banking, in order to improve productivity levels through a substantial reduction in service delivery costs. According to Avkiran (2000), the use of new information technology is one of the most cost effective ways for the delivery of financial services. However, in order to achieve greater competition better regulatory frameworks need to be introduced in order to make sure that public monopolies are not replaced by private ones.

Second, individual financial institutions at the behest of the central bank should be encouraged to tackle their individual weaknesses as identified from this study. For example, the NDB has performed poorly in terms of productivity change using all three approaches. This appears to be due to a combination of both poor efficiency and technical change, but mainly the former. Further analysis suggests that the poor efficiency performance is primarily related to a poor scale efficiency performance. It is clear, 
however, that a one size fits all approach to financial sector reforms aimed at enhancing the performance of all financial institution will not be appropriate nor effective in the context of Botswana.

Finally, the results reported here should be benchmarked with that of other developing economies at a similar stage of economic development, with the objective of identifying in what areas financial sector performance should be better and what policies should be given changed in order to achieve this.

\section{Acknowledgements}

We wish to acknowledge two anonymous referees whose constructive inputs and comments improved an earlier version of this article. The usual caveat applies.

\section{References}

Ataullah, A. and Le, H. (2006) 'Economic reforms and bank efficiency in developing countries: the case of the Indian banking industry', Applied Financial Economics, Vol. 16, No. 9, pp.653-663.

Avkiran, N.K. (2000) 'Rising productivity of Australian trading banks under deregulation 1986-1995', Journal of Economics and Finance, Vol. 24, No. 2, pp.122-140.

Bank of Botswana (BoB) (1999) 'Annual report', Gaborone.

Bank of Botswana (BoB) (2007) 'Annual report', Gaborone.

Berg, S.A., Forsund, F.R. and Jansen, E.S. (1992) 'Malmquist indices of productivity growth during the deregulation of Norwegian banking', Scandinavian Journal of Economics, Vol. 94, Suppl., pp.211-228.

Canhoto, A. and Dermine, J. (2003) 'A note on banking efficiency in Portugal, new vs. old banks', Journal of Banking and Finance, Vol. 27, No. 11, pp.2087-2098.

Chen, X., Skully, M. and Brown, K. (2005) 'Banking efficiency in China: application of DEA to pre and post deregulation eras 1993-2000', China Economic Review, Vol. 16, No. 3, pp.229-245.

Coelli, T.J., Rao, D.S.P., O’Donnell, C.J. and Battese, G.E. (2005) 'An introduction to efficiency and productivity analysis', New York: Springer Science and Business Media.

Das, A. and Ghosh, S. (2006) 'Financial deregulation and efficiency: an empirical analysis of Indian banks during the post reform period', Review of Financial Economics, Vol. 15, No. 3, pp.193-221.

Drake, L. (2001) 'Efficiency and productivity change in UK banking', Applied Financial Economics, Vol. 11, No. 5, pp.557-571.

Fare, R., Grosskopf, S., Yaisawang, S., Li, S.K. and Wang, Z. (1990) 'Productivity growth in Illinois electricity utilities', Resources and Energy, Vol. 12, No. 4, pp.383-398.

Favero, C.A. and Papi, L. (1995) 'Technical efficiency and scale efficiency in the Italian banking sector: a non-parametric approach', Applied Economics, Vol. 27, No. 4, pp.385-395.

Isik, I. and Hassan, M.K. (2003) 'Financial deregulation and total factor productivity change: an empirical study of Turkish commercial banks', Journal of Banking and Finance, Vol. 27, No. 8, pp.1455-1485.

Jeanneney, S.G., Hua, P. and Liang, Z. (2006) 'Financial development, economic efficiency and productivity growth: evidence from China', The Developing Economies, Vol. 44, No. 1, pp.27-52. 
Jefferis, K. (2007) Enhancing Access to Banking and Financial Services in Botswana, Gaborone: Finmark Trust and Econsult.

Leightner, J.E. and Lovell, C.A.K. (1998) 'The impact of financial liberalisation on the performance of Thai banks', Journal of Economics and Business, Vol. 50, No. 2, pp.115-131.

Mukherjee, K., Ray, S.C. and Miller, S.M. (2001) 'Productivity growth in large US commercial banks: the initial post-deregulation experience', Journal of Banking and Finance, Vol. 25, No. 5, pp.913-937.

Neal, P. (2004) 'X-efficiency and productivity change in Australian banking', Australian Economic Papers, Vol. 43, No. 2, pp.174-191.

Paxton, J. (2006) 'Technical efficiency in the rural financial sector: evidence from Mexico', The Journal of Developing Areas, Vol. 39, No. 2, pp.101-119.

Sacerdoti, E. (2005) 'Access to bank credit in sub-Saharan Africa: key issues and reform strategies', IMF Working Paper WP/05/166, Washington, DC.

Sathye, M. (2003) 'Efficiency of banks in a developing economy: the case of India', European Journal of Operational Research, Vol. 148, No. 3, pp.662-671.

Siphambe, H.K., Narayana, N., Akinkugbe, O. and Sentsho, J. (2005) Economic Development of Botswana: Facets, Policies, Problems and Prospects, Gaborone: Bay Publishing.

Thanassoulis, E. (2001) Introduction to the Theory and Application of Data Development Analysis, USA: Kluwer Academic Publishers.

Worthington, A.C. (1999) 'Malmquist indices of productivity change in Australian financial services', Journal of International Financial Markets, Institutions and Money, Vol. 9, No. 3, pp.303-320.

\section{Notes}

1 The data for both bank and non-bank institutions were obtained from their annual financial statements available in their annual reports for the years 2001-2006.

2 Two of which, the First National Bank and Botswana Development Corporation, corresponded with results obtained from the value added approach.

3 None of these institutions overlapped with those obtained from the value added and intermediate approaches.

4 Geometric means of the indices. 